\title{
Evaluation of SSR and SNP markers in Rubus glaucus Benth progenitors selection
}

\author{
Ana María López ${ }^{1}$, Carlos Felipe Barrera ${ }^{2}$, Marta Leonor Marulanda ${ }^{3}$
}

Abstract -Rubus glaucus Benth (known as "mora de castilla") is a Colombian agricultural product, with probably, the major potential. This fruit combines features of Idaeobatus and Rubus subgenera. Despite its recognized importance in the economy of small producers, this crop has received little technological development; as a result, sowing procedures of this specie is done by using local cultivars asexually propagated by producers. Associated Rubus producers in Colombia has noticed the necessity to formalize the offer of planting material, starting with plant breeding programs tending to the obtention of more productive varieties with morphological features that facilitates cultural activities. This study presents the results of the evaluation of SSR and SNPs markers obtained in previous experimental works from a RNA-Seq transcriptome analysis. It was evaluated 15 promissory $R$. glaucus cultivars, which could be potential progenitors in future breeding schemes. Genetic characterization was accomplished by testing 22 SSR microsatellite and 78 single nucleotide polymorphisms (SNPs) markers. From evaluated SSR markers, 15 yielded positive PCR amplification generating 29 loci and 58 alleles. From evaluated SNPs markers, 36 yielded positive PCR amplification. Obtained sequences from amplified products with SNPs showed high homology with species belonging to Rosaceae family. Selection criteria of progenitors were based on the results of molecular characterizations and useful morphological features in the culture management. This research demonstrates the utility of molecular markers to assess genetic diversity of potential progenitors susceptible to plant breeding processes.

This process, highly known as development of parental populations, determines in a great manner the success of plant breeding processes.

Index terms: Plant breeding, andean blackberry, genetic diversity.

Corresponding author: alopez@utp.edu.co

Received: July 19, 2018 Accepted: November 27, 2018

Copyright: All the contents of this journal, except where otherwise noted, is licensed under a Creative Commons Attribution License.

\section{$($ (c) $) \mathbf{E Y}$}

\section{Avaliação dos marcadores SSR e SNP na seleção de progenitores em Rubus glaucus Benth}

Resumo-Amora de castilla (Rubus glaucus Benth) é um dos produtos com maior potencial de desenvolvimento agrícola Colômbiano, que combina características dos subgéneros Idaeobatus e Rubus. Apesar da sua reconhecida importância na geração de rendas para os pequenos produtores, este cultivo tem recebido pouco desenvolvimento tecnológico. Como resultado a semeadura desta espécie é feita mediante cultivares locais propagados asexualmente pelos agricultores. Os produtores associados de amora na Colômbia têm ressaltado a necessidade de formalizar a oferta de cultivares para semente, começando com processos de fito-melhoramento para obter variedades mais produtivas, com características morfológicas que ajudem nas atividades culturais. O presente artigo, mostra os resultados da avaliação com marcadores tipo SSR e SNP obtidos em trabalhos prévios desde uma análise do transcriptoma por ARN-Seq. Quinze cultivares promissórios de $R$. glaucus foram avaliados para ser possivelmente utilizados num futuro processo de cruzamento. $\mathrm{Na}$ caracterização, 22 marcadores tipo SSR e 78 marcadores polimórficos tipo SNP foram selecionados. Dos 22 marcadores SSR usados, 15 rendeu amplificação positiva gerando um total de 29 loci e 58 alelos. Similarmente, dos 78 marcadores tipo SNP avaliados, 36 mostraram amplificação positiva. As sequencias obtidas dos produtos amplificados com SNP mostraram uma alta homologia com espécies da família Rosaceae. Os critérios de seleção dos progenitores foram realizados com base em os resultados das caracterizações moleculares junto com os critérios morfológicos úteis no manejo do cultivo. Este trabalho prova a utilidade dos marcadores moleculares para estimar a diversidade genética dos possíveis progenitores para ser usados num processo de fito-melhoramento. Um aspecto conhecido como o desenvolvimento da população parental, e que determina de uma forma grande o sucesso dos processos de fito-melhoramento.

Termos para indexação: Fito-melhoramento, amora de castilla, diversidade genética.

${ }^{1}$ PhD Fellow (Universidad de Caldas). Universidad Tecnológica de Pereira. Plant Biotechnology Laboratory. Pereira-Colombia. E - mail: alopez@utp.edu. co (ORCID 0000-0002-5138-1806)

${ }^{2} \mathrm{PhD}$. Universidad Nacional de Colombia - Medellín. Agricultural Sciences Faculty.Arauca-Colombia E-mail: cfbarreras@unal.edu.co(ORCID 0000-0002-5015-2956) ${ }^{3} \mathrm{PhD}$. Universidad Tecnológica de Pereira. Research, Innovation and Extension Vice-chancellory. Pereira-Colombia. E - mail: mlmarulanda@utp.edu.co ${ }^{\text {(ORCID }}$ 0000-0002-5015-2956) 


\section{Introduction}

Rosaceae family comprises nearly 90 genera and 300 species, among them fruit trees with economic importance are included such as apples (Malus pumila Mill.) and pears (Pyrus spp.); stone fruits or drupes like peaches (Prunus persica); several ornamental species including the rose (Rosa spp.), and soft fruits as strawberries, raspberries, blackberries, among others. Different taxonomic classifications of the family has been proposed based upon morphology, whilst SchulzeMenz (1964) suggested a new family classification into subfamilies: Maloideae, Amygdaloideae, Rosoideae y Spiraeoideae based on chromosome number and fruit type (LONGHI, et al. 2014).

Genetic variability of Rubus genus is known over the world and has been widely studied over the phenotypical, morphological, chromosomal and molecular aspects (DOSSETT, et al. 2012; ALICE, et al. 1999; GRAHAM AND MCNICOL, 1995; GRAHAM et al., 1997). One of the most interesting features of the genus is the variability in the number of chromosomes, polyploidy and hybridization; in contrast, only Idaeobatus, Dalibarda, and Anoplobatus subgenera are predominantly diploid, whilst Dalibardastrum, Malachobatus, and Orobatus are exclusively polyploid (THOMPSON, 1995, 1997). Hybridization in Rubus occurs mainly between closely related species (NARUHASHI, N., 1990; KRAFT, 1995) and, in some cases, between subgenera (JENNINGS, 1979; WEBER, 1996; ALICE, et al. 1997), thus, some intersubgeneric hybrids possess commercial importance (WAUGH, et al. 1990).

Rubus glaucus or Andean blackberry is distributed over the main Colombian mountain and combines Idaeobatus and Rubus features. This specie is a fertile amphidiploid or allotetraploid, probably originated by genome fusion of two species (JENNINGS, 1988). (DELGADO, et al. 2010) found 28 chromosomes in $R$. glaucus cultivars, assuming a basic number $\mathrm{n}=7$ for $R$ Rubus genus, it confirms its tetraploidy $(4 \mathrm{x})$.

Despite its well-known importance in the income generation for small producers, this cultivar has received little technological development, as a result, cultivar quality and productivity shown high variability, mainly due to the lack of formal varieties and the scarcity of planting material with good genetic and phytosanitary quality. Nowadays, planting of this specie is still done by the usage of local cultivars asexually propagated by growers (LOBO et al., 2002). This specie shows low yielding rates, mainly caused by anthracnose caused by por Glomerella cingulata (Stoneman) Spauld \& H. Schrenk (teleomorph state of Colletotrichum gloeosporioides). This disease is considered the most devastating affecting $R$. glaucus, creating losses above the 50\%. In addition, chemical treatment of this agent increases production costs
(SALDARRIAGA-CARDONA, et al. 2008).

Associated Colombian blackberry producers, has highlighted the necessity to formalize the offer of planting material, starting by plant breeding schemes that allow the obtention of more productive varieties with morphological features that facilitates cultural activities and certain tolerance to fungal attack, especially those related to anthracnose. It is well known that the first step in plant breeding programs is the selection and characterization of promising cultivars.

In this regards, (BERTRAND, et al. 2008) has stated that with help of polymerase chain reaction (PCR), public institutions and commercial organizations in charge of plant breeding programs has implemented molecular markers, including SSR and progenitor genotyping to make more efficient those processes. In addition, the evolution of molecular techniques developed the polymorphisms of a single nucleotide (SNP). Bertrand et al. (2008), classified selection schemes assisted by markers onto 5 areas: 1) Development of parental population for its selection and hybridization, 2) construction of ligation maps for its evaluation over phenotypical features, 3) QTL (Quantitative trait loci) validation, confirming the position and effects of QTL, 4) Selection assisted by markers, and 5) marker validation (BERTRAND, et al. 2008).

In Colombia, some studies regarding genetic diversity of Rubus genus has been carried out: Zamorano et al. (2004) conducted a molecular and morphological characterization of species belonging this genus using Random Amplified Microsatellite (RAMS). Duarte et al. (2011) evaluated genetic relations of elite Colombian Rubus glaucus cultivars through AFLP analysis obtained by the employment of three primer combinations. (MARULANDA, et al. 2007) assessed genetic diversity of wild and cultivated species of $R$. robustus, $R$. urticifolius, $R$. glaucus and $R$. rosifolius through AFLP and SSR markers developed for $R$. alceifolius (heterologous markers, when applied to $R$. glaucus). Marulanda and López (2009), performed molecular (SSR markers) and morpho-agricultural charcaterization for cultivated and wild varieties of Rubus glaucus with and without thorn, paying special attention to fruit size. (MARULANDA, et al. 2012) developed especific SSR markers for Rubus glaucus, aiming to obtain higher discrimination power. They concluded the necessity to develop more discriminatory molecular markers associated to morphological desired features. (LÓPEZ-VÁSQUEZ, et al. 2013), found differential responses in blackberry cultivars against anthracnose attack.

In recent years, it has been carried out the differential expression of blackberry cultivars against to anthracnose (Colletotrichum gloeosporioides) through transcriptome analysis (RNA-Seq) where two cultivars (UTP-1, tolerant \& UTP-4, susceptible) were inoculated with a highly pathogenic strain of $C$. gloeosporioides, 
together with a control treatment (cultivar inoculated with sterile water). Afterwards, RNA was extracted 72 hours later and the genetic material sequencing were compared between treatments (unpublished results). This study allowed the design of new molecular markers (SSR and SNPs) which were finally used in this project.

In order to start with plant breeding processes for Rubus glaucus, evaluations with SSR and SNPs were conducted over promissory cultivars that potentially could be used in future breeding schemes. Genetic distance and other features such as thorn presence/absence and fruit size were considered at the time of selecting cultivars.

\section{Materials and methods}

Plant material and DNA extraction - Fifteen Andean blackberry cultivars with agricultural interesting features coming from participative selections made with producers in different regions of the country were selected. These cultivars were previously characterized with heterologous (transferred from other Rubus specie) and homologous SSR markers (developed for R. glaucus) (MARULANDA, et al. 2012). Selected cultivars shown differential response against $C$. gloeosporioides attack (LÓPEZ-VÁSQUEZ, et al. 2013). Table 1, gather all data related to the sampled material (name, place of collection, thorn presence/absence and response against C. gloeosporioides (MORALES, et al. 2010).
DNA extraction of healthy foliar tissue was accomplished using the commercial Plant DNeasy Mini Kit (QIAGEN) following manufacturer instructions.

Molecular marker development - The development of the SSR and SNPs markers from a previous RNA-Seq analysis of the $R$. glaucus interaction against $C$. gloeosporioides, and its further use in this study is described.

SSR molecular markers - Detection of the simple sequence repeats (SSR) from the transcriptome analysis was completed using the MIcroSAtellite (MISA) software. From these sequences, 22 primers were designed. Rubus glaucus genome possess several microsatellite with different repetitions and lengths, as well as the majority of plant genomes analyzed so far. Thus, it was decided to select sequences with longer repetition than tri- nucleotides given that they has demonstrated to be more polymorphic and reproducible than microsatellite with $d i$-nucleotide repetitions (VUKOSAVLJEV, et al. 2015; FAN, et al. 2013). Primer design was limited to sequences with a high number of repetitions of the base unit ( $>5$ for tri- nucleotide and $>4$ for repetitions bigger than tetra- nucleotides). Another criterion were to select primers with annealing temperatures between $58^{\circ} \mathrm{C}$ and $61^{\circ} \mathrm{C}$ and expected PCR product sizes between 100 and 200 base pairs (bp) (see Table 2). In addition, Table 3 shows homology of generated primer sequences with other Rosaceae family species.

Table 1. Description of promissory $R$. glaucus cultivars.

\begin{tabular}{|c|c|c|c|c|c|c|}
\hline Code & $\begin{array}{l}\text { Latitude } \\
\text { (N) }\end{array}$ & $\begin{array}{l}\text { Longitude } \\
\text { (W) }\end{array}$ & $\begin{array}{l}\text { Height } \\
\text { (m. a. s. l.) }\end{array}$ & $\begin{array}{c}\text { Thorn } \\
\text { Presence/ } \\
\text { Absence }\end{array}$ & $\begin{array}{l}\text { Collect } \\
\text { Place }\end{array}$ & $\begin{array}{c}\text { Response against Colletotrichum } \\
\text { gloeosporioides" attack }\end{array}$ \\
\hline UTP1 & $4^{\circ} 52^{\prime} 15.0^{\prime \prime}$ & $75^{\circ} 37^{\prime} 32.4^{\prime \prime}$ & 2000 & Absence & Risaralda & Tolerant \\
\hline UTP2 & $4^{\circ} 39^{\prime} 7^{\prime \prime}$ & $75^{\circ} 35^{\prime} 26.3^{\prime \prime}$ & 2014 & Presence & Quindío & Tolerant \\
\hline $\mathrm{UTP} 3 * *$ & $4^{\circ} 38^{\prime} 36^{\prime \prime}$ & $75^{\circ} 28^{\prime} 41,5^{\prime \prime}$ & 2300 & Absence & Quindío & Moderately tolerant \\
\hline $\mathrm{UTP} 4 * *$ & $4^{\circ} 48^{\prime} 99.2^{\prime \prime}$ & $75^{\circ} 41^{\prime} 86^{\prime \prime}$ & 1950 & Presence & Risaralda & Very susceptible \\
\hline UTP5 & $5^{\circ} 2^{\prime} 2.7^{\prime \prime}$ & $75^{\circ} 27^{\prime} 10.5^{\prime \prime}$ & 1800 & Presence & Caldas & Very susceptible \\
\hline UTP6 & $4^{\circ} 44^{\prime} 45.1^{\prime \prime}$ & $75^{\circ} 36^{\prime} 39.6^{\prime \prime}$ & 1850 & Absence & Risaralda & Moderately tolerant \\
\hline UTP7 & $4^{\circ} 11^{\prime} 36.1 ”$ & $75^{\circ} 48^{\prime} 14.6^{\prime \prime}$ & 2000 & Absence & Quindío & Moderately tolerant \\
\hline UTP11 & $4^{\circ} 79^{\prime} 33^{\prime \prime}$ & $74^{\circ} 42^{\prime} 68^{\prime \prime}$ & 2288 & Absence & Cundinamarca & Moderately tolerant \\
\hline UTP15 & $6^{\circ} 99^{\prime} 44^{\prime \prime}$ & $72^{\circ} 98^{\prime} 80^{\prime \prime}$ & 2157 & Absence & Santander & Tolerant \\
\hline UTP16 & 659’39’.1 & $72^{\circ} 59^{\prime} 13^{\prime \prime}$ & 2176 & Presence & Santander & Very susceptible \\
\hline UTP20** & $4^{\circ} 13^{\prime} 23.8^{\prime \prime}$ & 76²5’35.9”' & 2380 & Presence & $\begin{array}{c}\text { Valle } \\
\text { del Cauca }\end{array}$ & Very susceptible \\
\hline UTP21 & $4^{\circ} 13^{\prime} 23.8^{\prime \prime}$ & $76^{\circ} 25^{\prime} 35.9^{\prime \prime}$ & 2380 & Presence & $\begin{array}{c}\text { Valle } \\
\text { del Cauca }\end{array}$ & Very susceptible \\
\hline UTP26 & $6^{\circ} 09^{\prime} 15.4^{\prime \prime}$ & $75^{\circ} 23^{\prime} 00.1^{\prime \prime}$ & 2000 & Absence & Antioquia & Moderately tolerant \\
\hline UTP27 & $6^{\circ} 09^{\prime} 15.4^{\prime \prime}$ & $75^{\circ} 23^{\prime} 00.1^{\prime \prime}$ & 2000 & Presence & Antioquia & Very susceptible \\
\hline $\mathrm{UTP} 28^{* *}$ & $6^{\circ} 09^{\prime} 15.4^{\prime \prime}$ & $75^{\circ} 23^{\prime} 00.1^{\prime \prime}$ & 2000 & Presence & Antioquia & Very susceptible \\
\hline
\end{tabular}

* (Morales, Y. M., Marulanda, M. L., ; Isaza, L., 2010).

** Cultivars with outstanding fruit size 
Amplification reactions for this type of markers was accomplished following described conditions by (MARULANDA, et al. 2012). The "touchdown" amplification profile consisted of 32 denaturing cycles at $95^{\circ} \mathrm{C}$ by 1 minute; annealing for 1 minute with decrease of $1{ }^{\circ} \mathrm{C}$ every two cycles from $63^{\circ} \mathrm{C}$ to $58^{\circ} \mathrm{C} ; 10$ cycles at $59^{\circ} \mathrm{C}$ and 10 cycles at $58^{\circ} \mathrm{C}$; elongation at $72^{\circ} \mathrm{C}$ for 1 minute.
Afterwards, amplicon visualization was conducted over denaturing $6 \%$ polyacrylamide electrophoresis gels. Obtained results was analyzed through GenAlex v6.2 (PEAKALL AND SMOUSE, 2006) and PAST (Paleontological statistics software package for education and data analysis) (HAMMER, et al. 2001). HardyWeinberg Equilibrium (HWE) analysis was evaluated employing the Markov chain in GenAlex v6.2 (PEAKALL AND SMOUSE, 2006). In the SSR analysis, it was also incorporated another specie belonging to Rubus genus as external group.

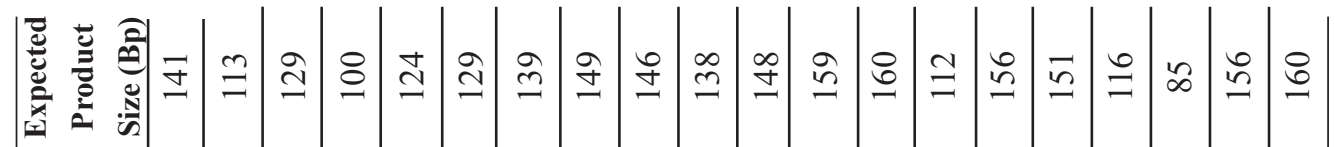

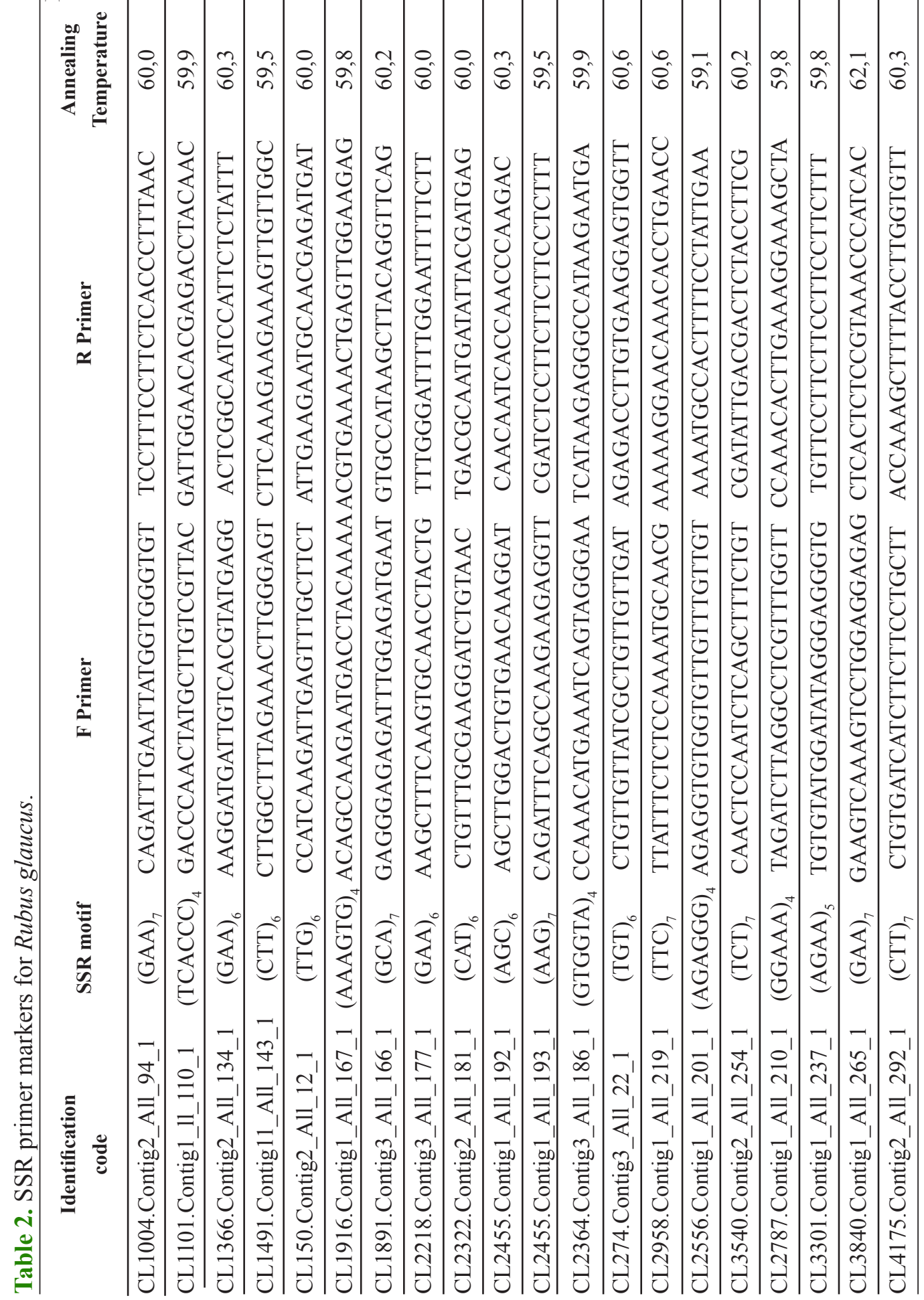


Table 3. Accession number and homologous sequences for developed SSR markers.

\begin{tabular}{|c|c|c|c|}
\hline \multirow[b]{2}{*}{ Identification code } & \multirow[b]{2}{*}{ Genbank Accession Number } & \multicolumn{2}{|c|}{ Homologous sequences in other rosaceae species } \\
\hline & & $\begin{array}{c}\text { Reported accession number in } \\
\text { other Rosaceae species }\end{array}$ & Specie \\
\hline CL1004.Contig2_All_94_1 & MH516338 & XM_024331960.1 & Rosa chinensis \\
\hline CL1101.Contig1_All_110_1 & MH516339 & XM_008365700.2 & Malus $x$ domestica \\
\hline CL1366.Contig2_All_134_1 & MH516340 & XM_024327521.1 & Rosa chinensis \\
\hline CL1491.Contig11_All_143_1 & MH516341 & $* * *$ & \\
\hline CL150.Contig2_All_12_1 & MH516342 & XM_004293478.2 & Fragaria vesca subsp. vesca \\
\hline CL1916.Contig1_All_167_1 & MH516343 & XM_024315090.1 & Rosa chinensis \\
\hline CL1891.Contig3_All_166_1 & MH516344 & XM_024315199.1 & Rosa chinensis \\
\hline CL2218.Contig3_All_177_1 & MH516345 & XM_021953392.1 & Prunus avium \\
\hline CL2322.Contig2_All_181_1 & MH516346 & XM_024325000.1 & Rosa chinensis \\
\hline CL2455.Contig1_All_192_1 & MH516347 & XM_020567229.1 & Prunus persica \\
\hline CL2455.Contig1_All_193_1 & MH516348 & XM_021972419.1 & Prunus avium \\
\hline CL2364.Contig3_All_186_1 & $* * *$ & XM_024325669.1 & Rosa chinensis \\
\hline CL274.Contig3_All_22_1 & $* * *$ & XM_024304460.1 & Rosa chinensis \\
\hline CL2958.Contig1_All_219_1 & $* * *$ & XM_009353829.2 & Pyrus x bretschneideri \\
\hline CL2556.Contig1_All_201_1 & $* * *$ & XR_002271838.1 & Prunus persica \\
\hline CL3540.Contig2_All_254_1 & $* * *$ & XM_024301335.1 & Rosa chinensis \\
\hline CL2787.Contig1_All_210_1 & $* * *$ & XR_907125.1 & Fragaria vesca subsp. vesca \\
\hline CL3301.Contig1_All_237_1 & $* * *$ & XM_007217879.2 & Prunus persica \\
\hline CL3840.Contig1_All_265_1 & $* * *$ & XM_021945224.1 & Prunus avium \\
\hline CL4175.Contig2_All_292_1 & $* * *$ & XM_024301524.1 & Rosa chinensis \\
\hline
\end{tabular}

SNP molecular markers - Bowtie2 v2.2.4 (LANGMEAD, et al. 2012) and samtools v0.1.19 (LI AND DURBIN, 2009) software were used in the SNP marker identification. Given that whole genome sequencing of Rubus glaucus had not been carried out so far, the Fragaria vesca genome was employed as reference genome, as well as the comparison between tolerant and susceptible samples. Finally, SNPs were identified in 200 genes from susceptible and tolerant $R$. glaucus against C. gloeosporioides, allowing the design of 78 primers. In addition, homology of generated primer sequences with Rosaceae family was evaluated. Table 4, present in detail primer sequences of the SNP markers (UNIGENE primers).

Amplification reactions for SNP markers was accomplished following described conditions by (MARULANDA, et al. 2012). The "touchdown" amplification profile consisted of 32 denaturing cycles at $95^{\circ} \mathrm{C}$ by 1 minute; annealing for 1 minute with decrease of $1{ }^{\circ} \mathrm{C}$ every two cycles from $64^{\circ} \mathrm{C}$ to $59^{\circ} \mathrm{C} ; 10$ cycles at $58^{\circ} \mathrm{C}$ and 10 cycles at $57^{\circ} \mathrm{C}$; elongation at $72^{\circ} \mathrm{C}$ for 1 minute.
SNP's fragment visualization was accomplished through gel electrophoresis and amplicons were sequenced by extension using the ABI PRISM ${ }^{\circledR}$ BigDyeTM Terminator Cycle Sequencing kit in a capillary ABI PRISM ${ }^{\circledR} 3730 X L$ (96 capillary type) sequencer.

To analyze SNP sequences and to corroborate homology of obtained data in the sequence, BLAST (Basic Local Alignment Search Tool - NCBI) tool was employed using an E- cutoff value of 0.000001. Then, an individual analysis of each UNIGENE consisting of a multiple sequence alignment with Clustal Omega (EMBL - EBI), online version (https://www.ebi.ac.uk/Tools/msa/ clustalo/). Finally, for the alignment of obtained sequences for all samples it was employed the MAFFT software, online version (www.ebi.ac.uk/Tools/mafft). A dendogram was obtained through the clustering method Neighbor Joining with UPGMA (Unweighted Pair Group Method with Arithmetic Mean), the substitution model proposed by (JUKES AND CANTOR, 1969) and a replacing number of 100. Genetic diversity parameters were estimated for haploid data with GenAlex 6.5b4 software (PEAKALL AND SMOUSE, 2006). 


\section{Results and discussion}

Microsatellite marker analysis - It was found 4799 simple sequence repeats consisting mainly of $d i$-nucleotide repetitions, followed by tri- and tetranucleotide repetitions. From the 22 evaluated SSR markers, 15 yielded positive amplification generating 29 loci and 58 alleles. Thirteen of them amplified 2 loci and the allelic number was about 15 . Informative alleles were approximately 3 (see Table 5). In that regards, (DOSSETT, et al. 2012) showed that when assessing genetic diversity in $R$. occidentalis cultivars using SSR markers, observed allelic diversity was low with 3 or least alleles in 15 of the 21 evaluated loci, similarly to the observed in this study where allelic number was set around 3.

Expected heterozygosity $(\mathrm{He})$ ranged between 0,607 and 0,7575; whilst observed heterozygosity (Ho) varied among 0,5665 and 1. Consequently, (GRAHAM, et al. 2004) explains that Rubus genus comprises highly heterozygous species. In that study Rubus idaeus varieties with thorn (e.g. Latham) are compared with glabrous ones (e.g. Glen Moy) demonstrating that thorn-possessing varieties showed higher heterozygosity levels than thorn-absent varieties. These differences associated to a morphological feature could support obtained values for $R$. glaucus, values that would be corroborated once progenies are established.

(DOSSETT, et al. 2012) argues that $R$. occidentalis cultivars show a noticeable heterozygosity level. For this specie in every evaluated locus (SSR), Ho was higher than He. Parallel, for Rubus glaucus this behavior was the same for the majority of markers (higher Ho values), excepting the marker CL2322. Additionally, (DOSSETT, et al. 2012) explains that this phenomena could be attributed to selection process and clonal propagation, similar situation to R. glaucus in Colombia where local selections made by producers are asexually propagated. Respect to variability parameters, (CLARK, et al. 2013) detected for R. fruticosus, a diploid specie with polyploidy ancestors and invasive behavior in United States, very low allele numbers, ranging between zero and 2,56 alleles per locus. That reported values are lower than obtained in the present study where the average value for polymorphic alleles was 5,448 . This behavior is supported considering that polyploidy species is expected to obtain higher values, such as R. glaucus.

In the HWE analysis, five markers were in equilibrium while the rest (10) showed significant or highly significant disequilibrium (Table 5). (FU, et al. 2016) reported that a loss of the HWE for the specie Ziziphus jujube is explained because there did not existed a random selection of the samples, similar to this case of study, where samples corresponded to selected and asexually propagated cultivars.
Genetic diversity estimation through Dice index allowed the construction of a dendogram, depicted in Figure 1. Detachment of cultivar UTP1 is explained considering its recognized tolerance to $C$. gloeosporioides attack in the RNA-Seq analysis. The presence of groups in the distance analysis evidence a geographical tendency, corroborating that the interchange of planting material in Colombia is apparent. The fact of thorn present/absent cultivar clustering contributes to the design of future breeding schemes.

(DOSSETT, et al. 2012) assessed the genetic diversity of cultivated and wild plants of $R$. occidentalis, a berry from temperate regions from North America and Europe, through the usage of 21 SSR markers aiming to stablish a plant breeding process over a germplasm bank that was thought to possess low diversity levels. This study raised the probability to perform the breeding process with higher levels of Ho in cultivated samples rather than wild ones, similar situation observed in the present study, where Ho in a general trend were higher than He. McCallum et al. (2016) carried out the construction of a ligation map for the auto-tetraploid specie, Vaccinium corymbosum, through SNPs and SSR markers obtained from a Genotyping by Sequencing (GBS) analysis, a technique that combines DNA fragmentation with restriction enzymes and its further sequencing with high performance tools. This work yielded 207 codominant primer pairs. Obtained SSR primers have made genetic characterizations more efficient by covering larger portions of the genome.

Previous works published by (MARULANDA, et al. 2007; 2012), have characterized $R$. glaucus cultivars transferring SSR markers from other Rubus species to $R$. glaucus, with positive polymorphic amplification for some markers and no amplification or monomorphic results for others, similarly to this study. With the use of the new SSR markers polymorphic amplification of the samples was achieved.

(LONGHI, et al. 2014; SALAZAR, et al. 2015) has reported that after the emergence of the Next Generation Sequencing (NGS) techniques, the Rosaceae specie Fragaria vesca has received the major SSR marker design derived from analysis using those techniques, with more than 4000 markers reported to the date. Other species including Malus spp, Prunus spp, Pyrus spp, Rosa spp. and Rubus spp., have also had significant developments (LONGHI, et al. 2014). The massive SSR development derived from high performance sequencing have triggered the use of these type of markers and have diminished costs associated to genetic characterizations at the time that new regions of the genome are covered. 


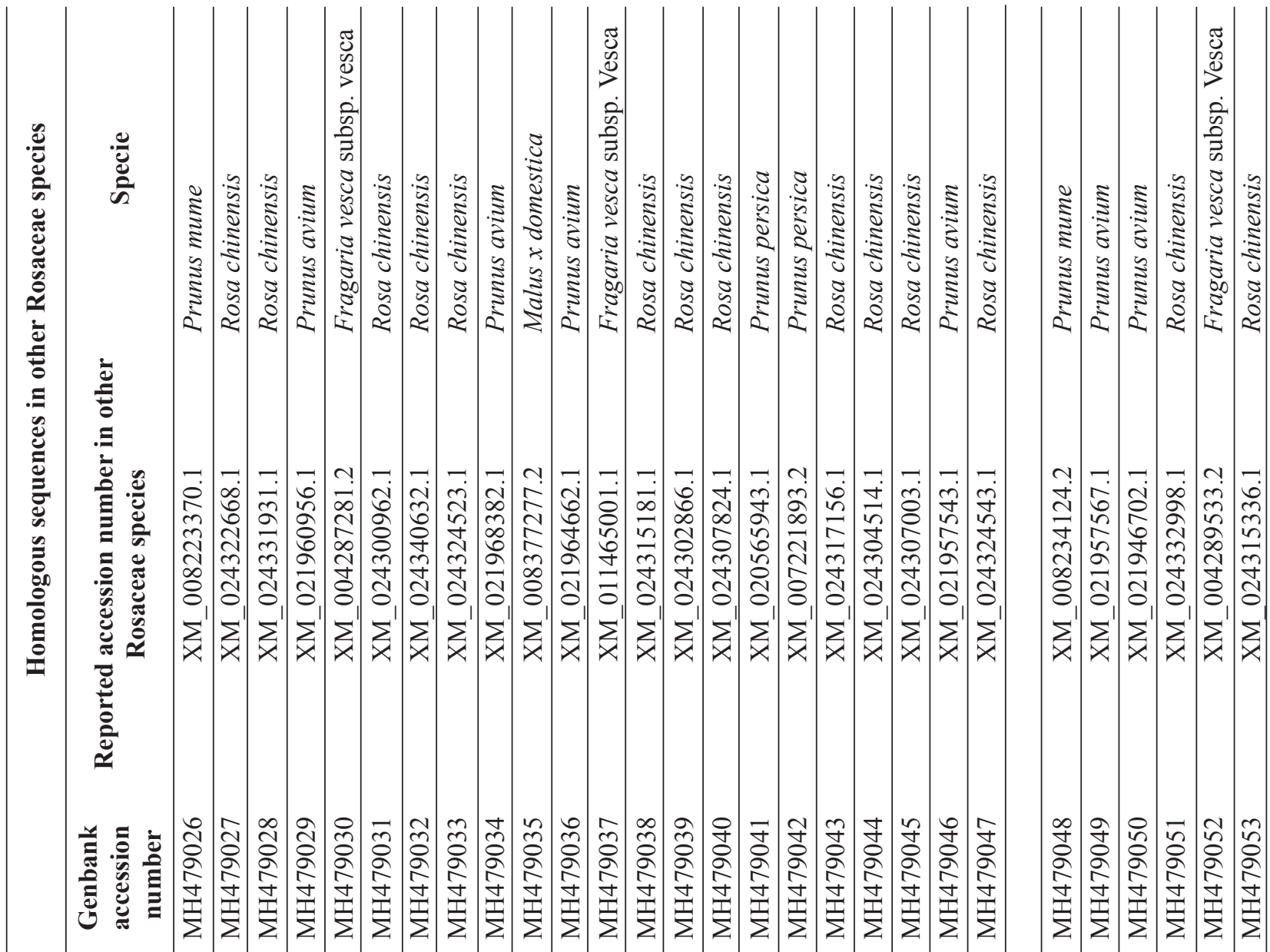

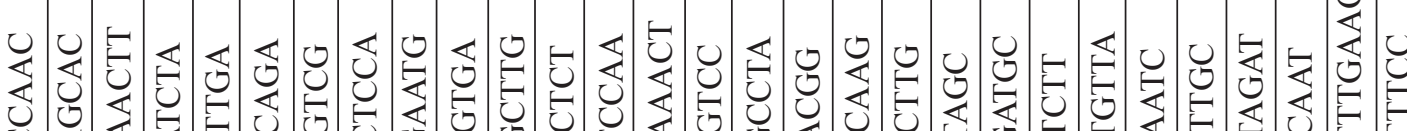
O

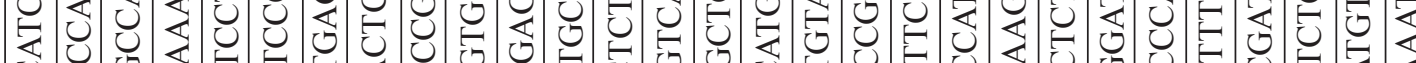
荌

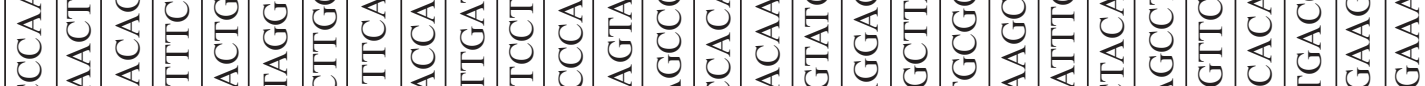

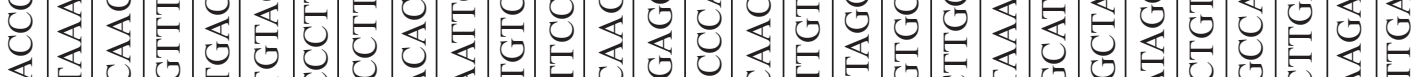
\begin{tabular}{l}
\hline \\
\hline
\end{tabular} 荌 导 O

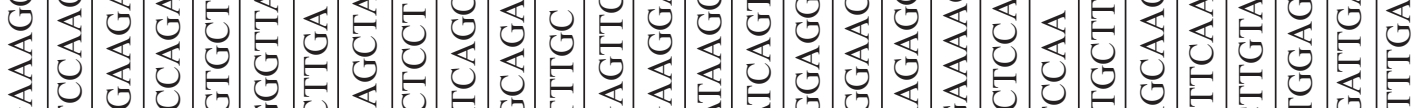

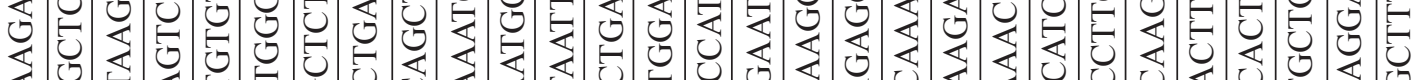

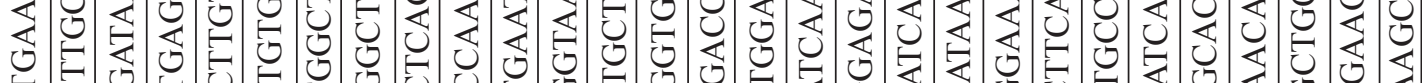
O

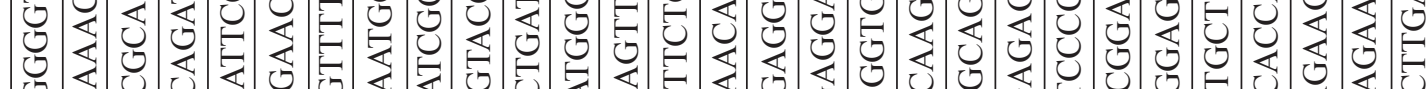

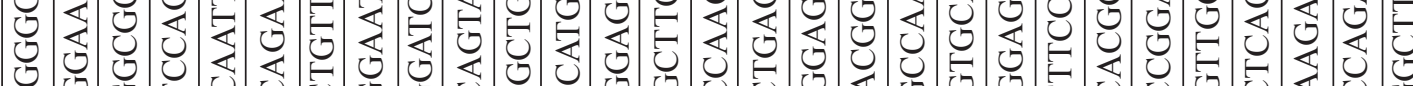
O

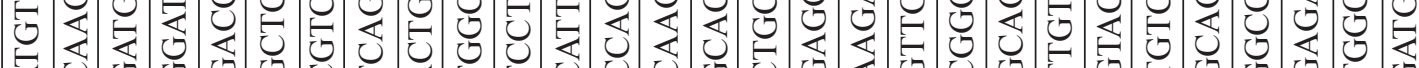

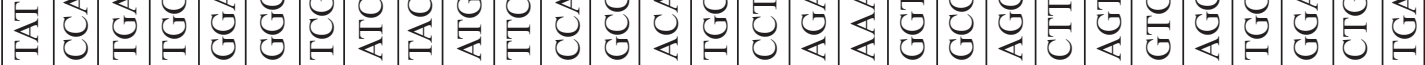




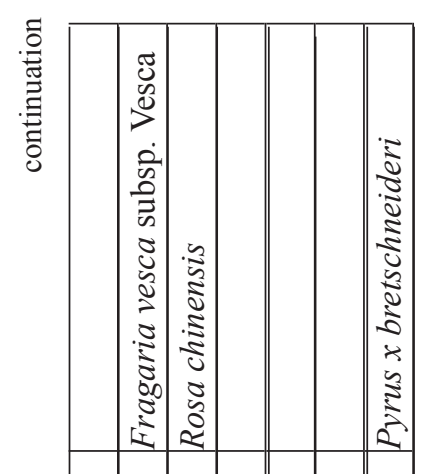

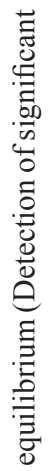

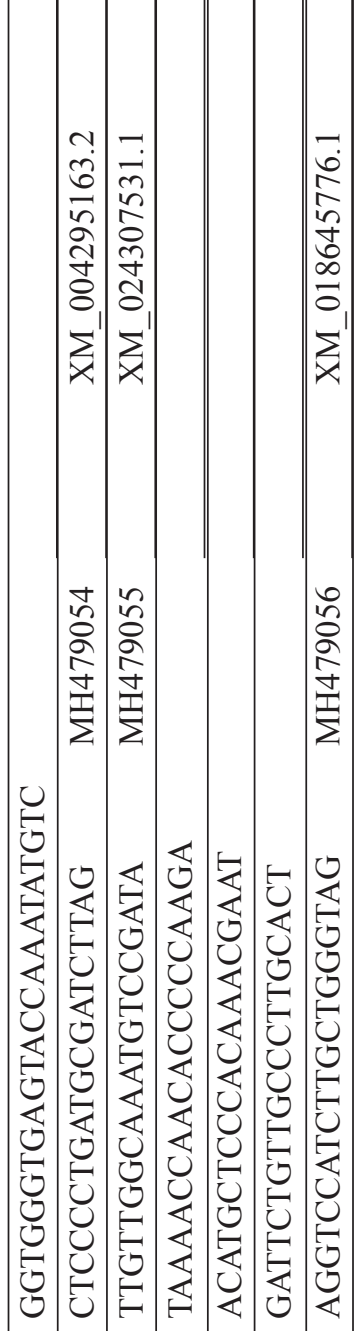

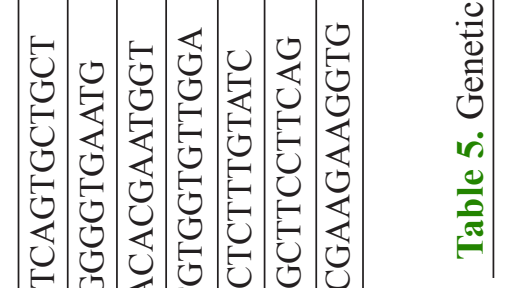

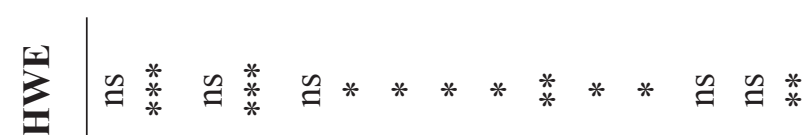

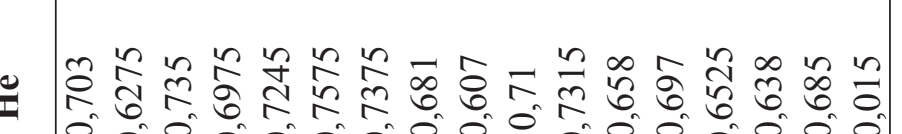
(1)

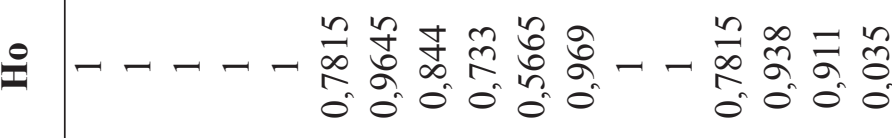

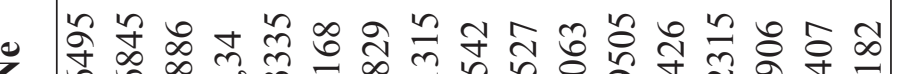
ले ले ते से ले ते ले ते ले ते ते ले

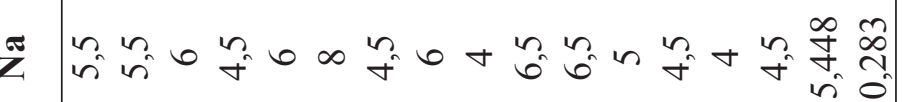

帘

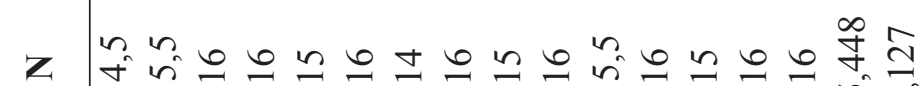

ז.

के

离

(1)

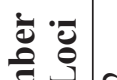

远承

蛋

:

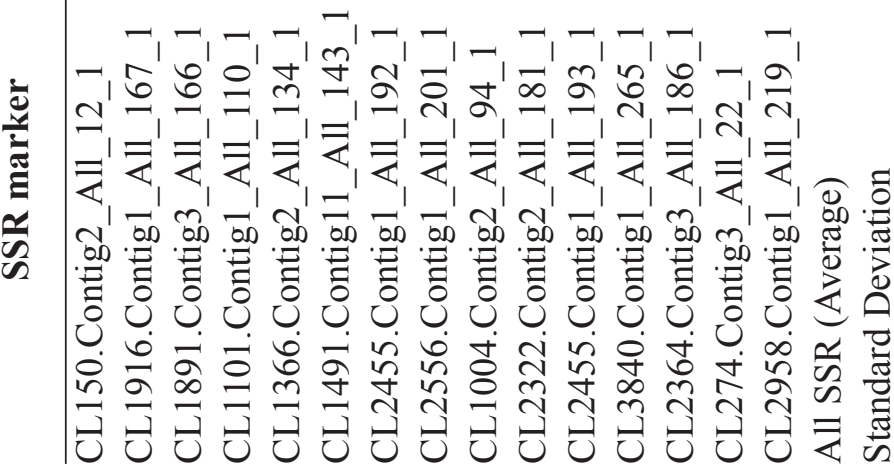

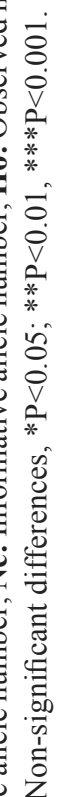

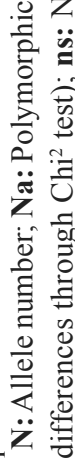




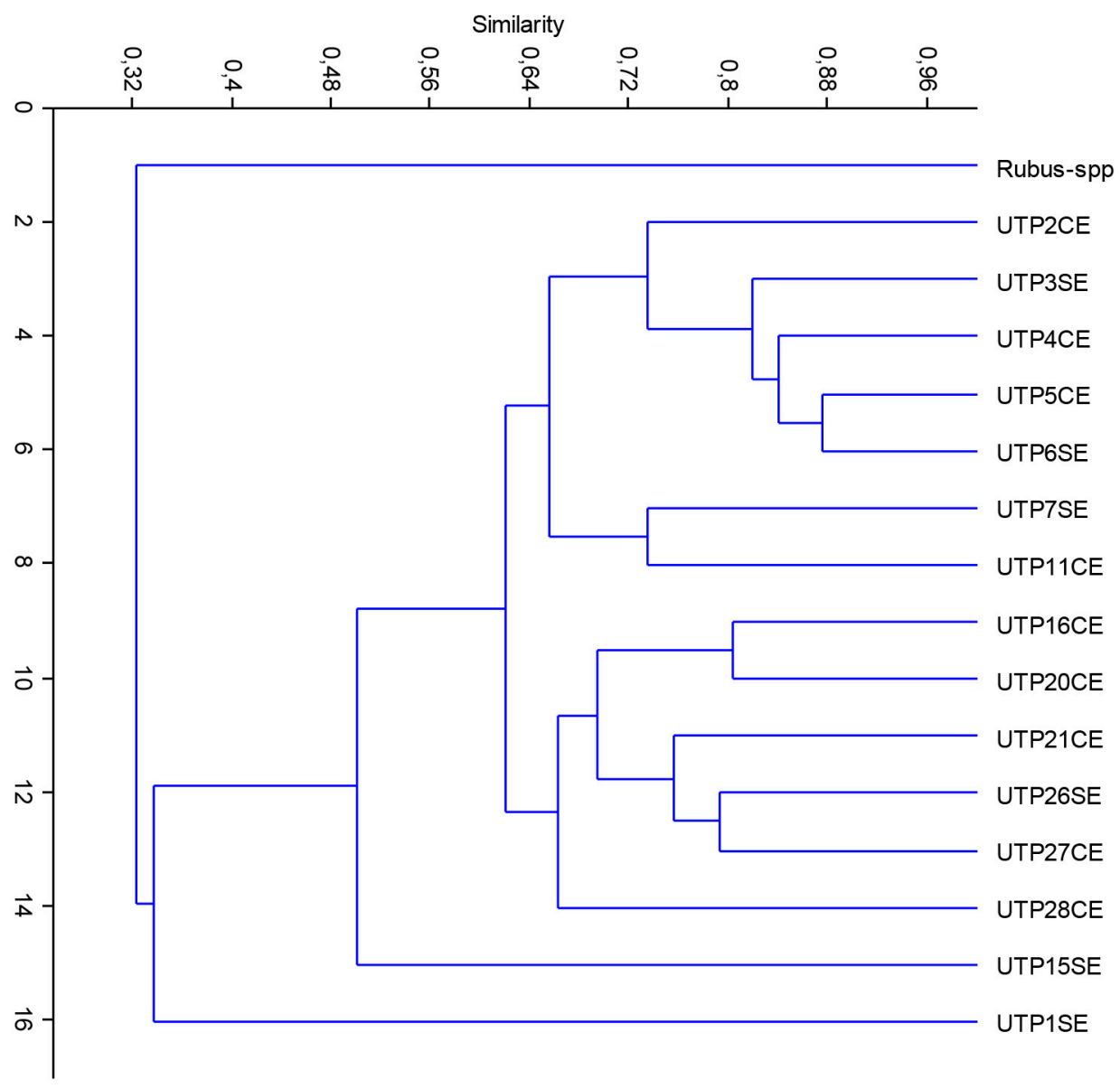

Figure 1. Dendogram obtained from SSR markers employing the Dice Index.

SNP marker analysis - From the 78 evaluated SNP-containing DNA fragments, 36-yielded positive amplification. Obtained amplicon sequences showed high homology with Rosaceae species: Prunus spp. (29\%); Fragaria vesca (23\%); Pyrus spp. (5\%); Malus spp. (2\%) (Table 4). Other homologies were established with species of other families $(9 \%)$ and another corresponded to sequences with non-reported homologies in public data bases (32\%). Using sequence alignments (Figure 2 ), a dendogram was constructed with the clustering method of Figure 3. This dendogram showed 4 clusters with any clustering tendency by morphologic features (thorn presence/absence) nor geographical origin. The first group comprises cultivars UTP1, UTP11, UTP6, UTP2; the second consisted of the UTP16, UTP21, UTP4, UTP 3 cultivars; the third clustered UTP15, UTP26, UTP5 and UTP27; and the fourth possessed the most distant cultivars, UTP7 and UTP28. Surprisingly, cultivars with desirables features (UTP1, UTP4 y UTP7) were located in different groups, an important annotation to guide the progenitor selection in breeding processes. Both SSR and SNP-derived dendograms allowed the progenitor selection with noticeable differences in their genomes.

Sequence homology result were consistent with other Rosaceae species. It is expected that $R$. glaucus shows high homology within its family to species that have complete or partially sequenced genomes. In addition, is important to state that the development of SNP markers from transcriptome analysis has been widely used in Prunus spp. (Rosaceae) to evaluate segregant populations of pears in Europe. The employment of SNP markers in the evaluation of germplasm banks of peaches and the construction of microarrays from transcriptome analysisderived SNPs in apples, have been also reported. Based in that evidence, the development of such methodologies have improve the selection processes in breeding programs (YAMAMOTO AND TERAKAMI, 2016). 
170502-085_B10_UTP6_SE_Unigene_37334.ab1 170502-085_P08_UTP5 CE Unigene 37334.ab1 170502-085_L08_UTP3_SE_Unigene_37334.ab1 170502-085_H08_UTP1_SE_Unigene_37334.ab1 170502-085 F10 UTP1̄ CE Unigene 37334 ab1 170502-085_D12_UTP28_CE_Unigene_37334.ab1 170502-085 B12 UTP2 7 CE Unigene 37334 ab1 170502-085_N08_UTP4 CE_Unigene_37334.ab1 170502-085_N10_UTP21_CE_Unigene_37334.ab1 170502-085 L10 UTP20 CE Unigene 37334.ab1 170502-085_H10_UTP15_SE_Unigene_37334.ab1 170502-085 J10 UTP16 CE Unigene $37334 . \mathrm{ab1}$ 170502-085_D10_UTP7_SE_Unigene_-̄ $7334 . \mathrm{ab1}$ 170502-085_J08_UTP2_CE_Unigene_37334.ab1 170502-085_P10_UTP2 $\overline{6}$ SEE_Unigene_37334.ab1
TAAAATGTTTGAAGCACTAACGAGTTCTACTCAAGCTTTAGTGCAAGGGCAACAGAATCC TAAAATGTTTGAAGCACTAACGAGTTCTACTCAAGCTTTAGTGCAAGGGCAACAGAATCC TAAAATGTTTGAAGCACTAACGAGTTCTACTCAAGCTTTAGTGCAAGGGCA.ACAGA.ATCC TAAAATGTTTGAAGCACTAACGAGTTCTACTCAAGCTTTAGTGCAAGGGCAACAGAATCC TAAAATGTTTGAAGCACTAACGAGTTCTACTCAAGCTTTAGTGCAAGGGCAACAGAдTCC TA.AATGTTTGA.GCACTAACGAGTTCTACTCAAGCTTTAGTGCAAGGGCAACAGAATCC TA.A.ATGTTTGAAGCACTAACGAGTTCTACTCAAGCTTTAGTGCAAGGGCAACAGAATCA TAAAATGTTTGAAGCACTAACGAGTTCTACTCAAGCTTTAGTGCAAGGGCAACAGAATCC TA.AATGTTTGAAGCACTAACGAGTTCTACTCAAGCTTTAGTGCAAGGGCAACAGAATCC TAдAдTGTTTGAAGCACTAACGAGTTCTACTCAAGCTTTAGTGCAдGGGCAдСдGAдTCC TAAAATGTTTGAAGCACTAACGAGTTCTACTCAAGCTTTAGTGCAAGGGCAACAGAATCC TA.AATGTTTGAAGCACTAACGAGTTCTACTCAAGCTTTAGTGCAAGGGCAACAGAATCC TAДAДTGTTTGA.GCACTAACGAGTTCTACTCAAGCTTTAGTGCAAGGGCAACAGA.ACA TA_AATGTTTGAAGCACTAACGAGTTCTACTCAAGCTTTAGTGCAAGGGCAACAGA_TCC TA.AATGTTTGAAGCACTAACGAGTTCTACTCAAGCTTTAGTGCAAGGGCAACAGAATCC

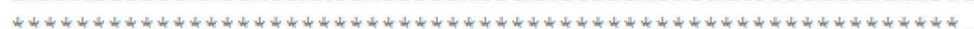

Figure 2. Segment of the sequence alignment with UNIGENE37334 with Clustal Omega software (EMBL-EBI), online version (https://www.ebi.ac.uk/Tools/msa/clustalo/).

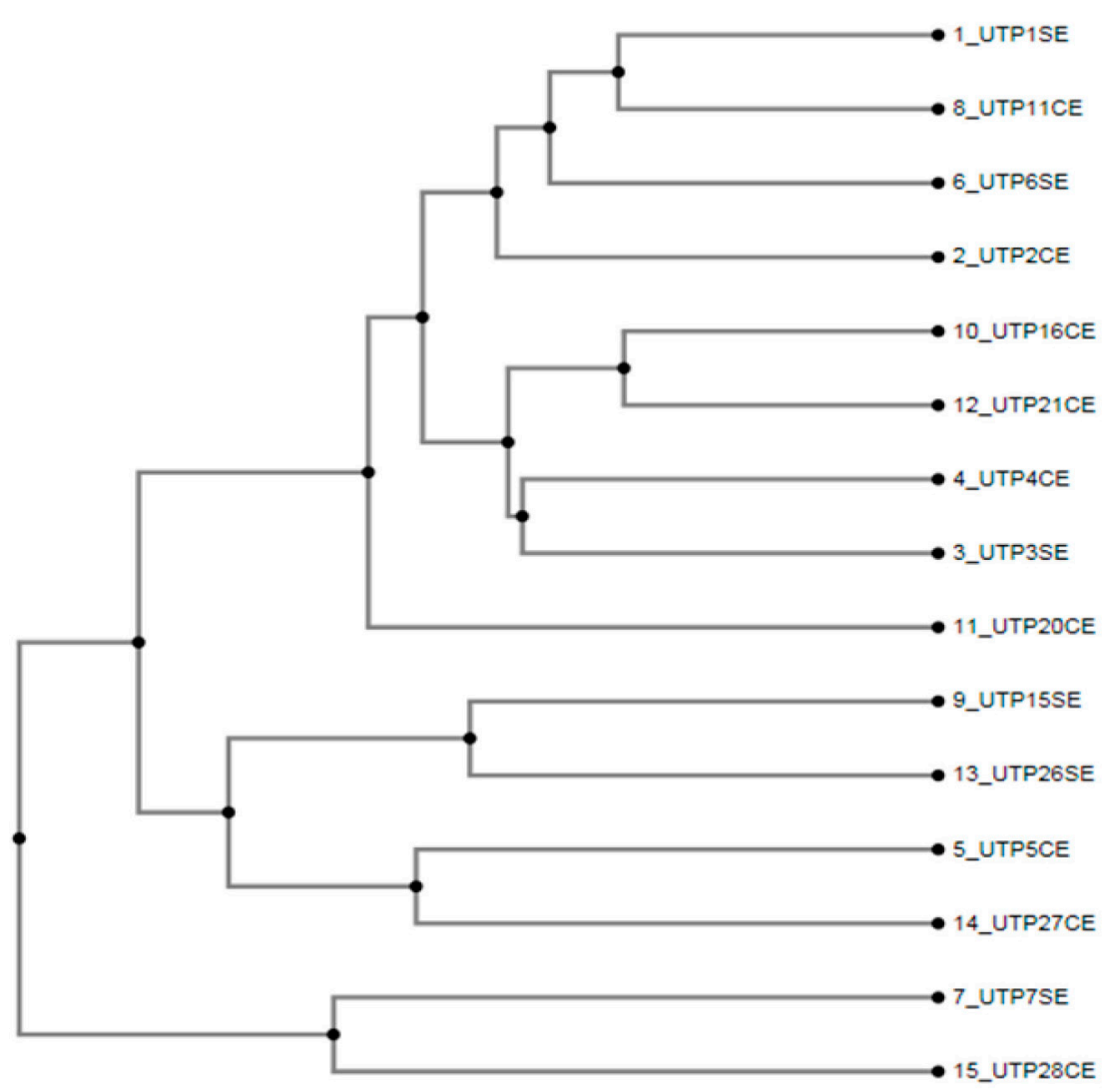

Figure 3. Dendogram obtained from SNP-containing DNA fragment alignments employing the Neighbor Joining clustering method.

Genetic diversity parameters for haplotypical data are presented in Table 6. It was found 1162 SNP-containing fragments, corresponding to 1082 effective SNPs and a polymorphism of $12,49 \%$. In regards to the specific nature of each SNP and SSR marker, biallelic nature of SNP markers makes their discrimination power lower than SSR. In that sense, the greater variability observed in SSR compared to SNPs allows better possibilities in the identification of cultivars and its genetic variability assessment (SÁNCHEZ-PÉREZ, et al. 2006), making them leading markers for genotyping, fine mapping or to increasing QTL resolution. 
Table 6. Genetic diversity parameters for haplotypical data obtained with SNP markers in R. glaucus.

\begin{tabular}{|l|c|c|}
\hline \multicolumn{1}{|c|}{ Parameter } & Average value & Standard deviation \\
\hline Number of SNP-containing regions & 1162 & 0.005 \\
\hline Number of SNP-containing effective regions & 1082 & 0.003 \\
\hline Percentage of polymorphic SNPs & $12.49 \%$ & ------ \\
\hline
\end{tabular}

Progenitor selection - Genetic diversity analysis between previously selected cultivars are used to recommend progenitors susceptible to be used in future breeding processes (Table 7). In order to make those recommendations, the morphologic features related to thorn presence/absence and C. gloeosporioides tolerance (very desirable features in new cultivars) were also considered; in that sense, tolerant or moderately tolerant without thorn material was privileged. Respect to cluster analysis, there were selected samples from different clustering groups. Moreover, cultivars UTP5, UTP20 and UTP2 8 possess, according to producers, fruits with greater size, making them very popular in Colombia, despite its thorn presence and significant susceptibility to C. gloeosporioides.

Table 7. Progenitor selection for future breeding schemes.

\begin{tabular}{|c|c|c|c|c|}
\hline Selected cultivar & Thorn presence/ absence & $\begin{array}{c}\text { Response against } \\
\text { C. } \text { gloeosporioides attack }\end{array}$ & $\begin{array}{c}\text { Cluster number } \\
\text { with SNPs }\end{array}$ & $\begin{array}{c}\text { Cluster number } \\
\text { with SSR }\end{array}$ \\
\hline UTP1 & Absence (SE) & Tolerant & 1 & 4 \\
\hline UTP5 & Presence (CE) & Very susceptible & 3 & 1 \\
\hline UTP7 & Absence (SE) & Moderately tolerant & 4 & 2 \\
\hline UTP11 & Absence (SE) & Moderately tolerant & 1 & 2 \\
\hline UTP20 & Presence (CE) & Very susceptible & 2 & 3 \\
\hline UTP28 & Presence (CE) & Very susceptible & 4 & 3 \\
\hline
\end{tabular}

(HE, et al. 2014), states that plant breeding can be performed through two main strategies, classic and molecular approaches. The classic process employs closely related varieties that could interbreed, whilst the molecular breeding consist in the application of molecular biology and biotechnology approaches to accomplish the development of new cultivars through the Marker-assisted Selection (MAS) and the genetic transformation (MOOSE AND MUMM, 2008). This work employed SSR and SNP markers in the development of a progenitor population aiming to move towards hybridization processes that permit an increase in the genetic gain.

\section{Conclusions}

This work evidence the utility of molecular markers to assess the genetic diversity of possible progenitors susceptible to be employed in future breeding processes. This aspect, widely known as the development of a parental population, determines in great manner the success of breeding schemes. The SSR and SNP markers employed in this study, allowed the characterization of such population studying different genome regions. Morphological and fungal tolerance selection criteria, previously evaluated, were also considered in the selection of six progenitors.

\section{Acknowledgements}

Authors express their thanks to Universidad Tecnológica de Pereira (Colombia) and the General System of Royalties (National Planning Department) for financing the research program "Development of scientific and technologies in biotechnology applied to the sectors of health and agro-industry in the department of Risaralda “identified with BPIN code 2012000100050.

This project was completed in the frame of the genetic access contract 195 (2018-05-25). 


\section{References}

ALICE, L.A.; ERIKSSON, T.; ERIKSEN, B.; CAMPBELL, C.S. Intersubgeneric hybridization between a diploid raspberry, Rubus idaeus, and a tetraploid blackberry, R. caesius (Rosaceae). American Journal of Botany, New York, v.84, p.171, 1997.

BERTRAND, C.; COLLARD, Y.; MACKILL, D. J. Marker-assisted selection: an approach for precision plant breeding in the twenty - firs century. Philosophical Transactions of the Royal Society of London Series B, Biological Sciences, New York, v.363, p.557-572, 2008.

CLARK, L.V.; EVANS, K.J.; JASIENIUK, M. Origins and distribution of invasive Rubus fruticosus L. agg. (Rosaceae) clones in the Western United States. Biological Invasions, Berlin, v.15, n.6, p.1331-1342, 2013.

DELGADO, L.; URIBE, M.; MARULANDA, M. L. Estandarización de la técnica citogenética "SQUASH". Scientia Et Technica, Pereira, v.17,n.46, p.74-79,2010.

DOSSETT, M.; BASSIL, N. V.; LEWERS, K.S.; FINN, C. E. Genetic diversity in wild and cultivated black raspberry (Rubus occidentalis L.) evaluated by simple sequence repeat markers. Genetic Resources and Crop Evolution, Dordrecht, v.59, n.8, p. 1849-1865, 2012.

DUARTE-DELGADO, D.; CHACÓN M. I.; NÚÑEZ, V.; BARRERO, L. S. Preliminary assessment of AFLP fingerprinting of Rubus glaucus Benth. elite genotypes. Agronomia Colombiana, Bogotá, v.29, n.1, p.7-16, 2011.

FAN, L.; ZHANG, M.Y.; LIU, Q.Z.; LI, L.T.; SONG, Y.; WANG, L.F.; ZHANG, S.L.; WU, J. Transferability of newly developed pear SSR markers to other Rosaceae species. Plant Molecular Biology Reporter, Dordrecht, v.31, n.6, p.1271-1282, 2013.

FU, P. C.; ZHANG, Y. Z.; YA, H. Y.; GAO, Q. B. Characterization of SSR genomic abundance and identification of SSR markers for population genetics in Chinese jujube (Ziziphus jujuba Mill.). Peer J, United State, v.4, p.1735, 2016.

GRAHAM, J. AND MCNICOL R.J. An examination of the ability of RAPD markers to determine the relationships within and between Rubus species. Theoretical and Applied Genetics, Berlin, v.90, p.7/8, p.1128-1132, 1995.
GRAHAM, J.; SMITH, K.; MACKENZIE, K.; JORGENSON, L.; HACKETT, C.; POWELL, W. The construction of a genetic linkage map of red raspberry (Rubus idaeus subsp. idaeus) based on AFLPs, genomicSSR and EST-SSR markers. Theoretical and Applied Genetics, Berlin, v.9, n.4, p.740-749, 2004.

GRAHAM, J.; SQUIRE, G. R.; MARSHALL, B.; HARRISON, R.E. Investigation of rubus breeding anomalies and taxonomy using RAPD analysis. Molecular Ecology, London, v.6, n.11, p.1001-1008, 1997.

HAMMER, Ø.; HARPER, D. A. T.; RYAN, P. D. PASTPalaeontological statistics. 2001. Disponível em: $\leq w w w$. uv. es/ $\sim$ pardomv/pe/2001_1/past/pastprog/past. Pdf $>$. Acesso em: 25 jul. 2001.

HE, J.; ZHAO, X.; LAROCHE, A.; LU, Z. X.; LIU, H.; LI, $Z$. Genotyping-by-sequencing (GBS), an ultimate markerassisted selection (MAS) tool to accelerate plant breeding. Frontiers in Plant Science, Lausane, v.5, p.484, 2014.

JENNINGS, D. L. Raspberries and blackberries: their breeding, diseases and growth. London: Academic Press, 1988. p.230.

JENNINGS, D. L. Resistance to Leptosphaeria coniothyrium in the red raspberry and some related species. Annals of Applied Biology, London, v.93, n.3, p.319-326, 1979.

JUKES, T. H. AND CANTOR, C. R. Evolution of protein molecules. Mammalian protein Metabolism, New York, v.3, p.21-132, 1969.

KRAFT, T.; NYBOM, H.; WERLEMARK, G. Rubus vestervicensis (Rosaceae) - its hybrid origin revealed by DNA fingerprinting. Nordic Journal of Botany, Oxford, v.15, n.3, p.237-242. 1995.

LANGMEAD, B.; SALZBERG, S. L. Fast gapped-read alignment with Bowtie 2. Nature Methods, New York, v.9. n.4, p.357-359, 2012.

LI, H.; DURBIN, R. Fast and accurate short read alignment with Burrows-Wheeler transform. Bioinformatics, New York, v.25, n.14, p.1754-1760, 2009.

LOBO, M.; MEDINA, C.L.; DELGADO, O.A.; ZULUAGA, M.L.; CARDONA, M.; OSORIO, A. Recursos genéticos de frutales andinos en el sistema de bancos de germoplasma del estado colombiano. In: SEMINARIO NACIONAL DE FRUTALES DE CLIMA FRÍO MODERADO, 4., 2002, Anais... Medellín. 
LONGHI, S.; GIONGO, L.; BUTI, M.; SURBANOVSKI, N.; VIOLA, R.; VELASCO, R.; \& SARGENT, D. Molecular genetics and genomics of the Rosoideae: state of the art and future perspectives. Horticulture Research, London, v.1, p.1-18, 2014.

LÓPEZ-VÁSQUEZ, J.; CASTAÑO-ZAPATA, J.; MARULANDA, M.; LÓPEZ, A. Characterization of Anthracnose resistance caused by Glomerella cingulata and productivity of five Andean blackberry genotypes (Rubus glaucus Benth.). Acta Agronómica, Palmira, v.62, n.2, p.174-185, 2013.

MARULANDA, M.L.; AND LÓPEZ, A.M. Characterization of thornless Rubus glaucus in Colombia. Canadian Journal of Pure \& Applied Sciences, Burnaby, v.3. n.3, p.875-885, 2009.

MARULANDA, M.L.; LÓPEZ, A.M.; AGUILAR, S.B. Genetic diversity of wild and cultivated Rubus species in Colombia using AFLP and SSR markers. Crop Breeding and Applied Biotechnology, Londrina, v.7, n.3, p.242$252,2007$.

MARULANDA, M.L.; LÓPEZ, A.M.; URIBE, M. Molecular characterization of the Andean blackberry, Rubus glaucus, using SSR markers. Genetics Molecular Research, Ribeirão Preto, v.11, p.322-331, 2012.

MCCALLUM, S.; GRAHAM, J.; JORGENSEN, L.; ROWLAND, L.J.; BASSIL, N.V.; HANCOCK, J.F.; WHEELER, E.J.; VINING, K.; POLAND, J.A.; OLMSTEAD, J.W.; BUCK, E.; WIEDOW, C.; JACKSON E.; BROWN, A.; HACKETT, C.A. Construction of a SNP and SSR linkage map in autotetraploid blueberry using genotyping by sequencing. Molecular Breeding, Dordrecht, v.36, p.1-24, 2016.

MOOSE, S.P.; MUMM, R.H. Molecular plant breeding as the foundation for 21 century crop improvement. Plant Physiology, Lancaster, v.147, p.969-977, 2008.

MORALES, Y. M.; MARULANDA, M. L.; ISAZA, L. Caracterización morfológica y patogénica de aislamientos del género Colletotrichum spp. causantes de la antracnosis en mora de castilla (Rubus glaucus Benth.) provenientes de los departamentos de Caldas, Quindío y Risaralda (Colombia). 2010. 53 f. Thesis (Doctor) - Facultad de Ciencias Básicas y Tecnologías, Universidad del Quindío, Quindio, 2010.

NARUHASHI, N. Rubus $\times$ semi-nepalensis, a new natural hybrid from Nepal Himalaya . Journal of Japanese Botany, Tokyo, v.65, n.6, p.186-191, 1990.
PEAKALL, R. O. D.; SMOUSE, P. E. GENALEX 6: genetic analysis in Excel. Population genetic software for teaching and research. Molecular Ecology Resources, Oxford, v.6, n.1, p.288-295, 2006.

SALAZAR, J. A.; RUBIO, M.; RUÍZ, D.; TARTARINI, S.; MARTÍNEZ-GÓMEZ, P.; DONDINI, L. SNP development for genetic diversity analysis in apricot. Tree Genetics \& Genomes, Heidelberg, v.11, p.15, 2015.

SALDARRIAGA-CARDONA, A.; CASTAÑO-ZAPATA, J.; ARANGO-ISAZA, R. Caracterización del agente causante de la antracnosis en tomate de árbol, manzano y mora. Revista de la Academia Colombiana de Ciencias Exactas, Físicas y Naturales, Bogotá, v.32, n.123, p.145$156,2008$.

SÁNCHEZ-PÉREZ, R.; MARTÍNEZ-GÓMEZ, P.; DICENTA, F.; EGEA, J.; RUIZ, D. Level and transmission of genetic heterozygosity in apricot (Prunus armeniaca L.) explored using simple sequence repeat markers. Genetic Resources and Crop Evolution, Dordrecht, v.53, n.4, p.763 - 770, 2006.

SCHULZE-MENZ, G. K. Rosaceae. In: MELCHIOR, H. Engler's syllabus der pflanzenfamilien. Berlin: Gerbruder Borntraeger, 1964. p.209-218.

THOMPSON, M. M. Chromosome numbers of Rubus species at the national clonal germplasm repository. HortScience, Alexandria, v.30, n.7, p.1447-1452, 1995.

THOMPSON, M. M. Survey of Chromosome Numbers in Rubus (Rosaceae: Rosoideae). Annals of the Missouri Botanical Garden, St Louis, v.84, p.128, 1997.

VUKOSAVLJEV, M.; ESSELINK, G.D.; VAN'TWESTENDE, W.P.; COX, P.; VISSER, R.G.; ARENS, P.; SMULDERS, M.J. Efficient development of highly polymorphic microsatellite markers based on polymorphic repeats in transcriptome sequences of multiple individuals. Molecular Ecology Resources, Oxford, v.15, n.1, p.17-27, 2015.

WAUGH, R.; VAN DE VEN, W.T.G.; PHILLIPS, M.S.; POWELL, W. Chloroplast DNA diversity in the genus Rubus (Rosaceae) revealed by Southern hybridization. Plant Systematics and Evolution, Wien, v.172, n.1/44, p.65-75, 1990.

WEBER, H. E. Former and modern taxonomic treatment of the apomicticrubus complex. Folia Geobotanica, Jena, v.31, n.3, p.373-380, 1996. 
YAMAMOTO, T.; TERAKAMI, S. Genomics of pear and other Rosaceae fruit trees. Breeding Science, Tolyo, v.66, n.1, p.148-159, 2016.
ZAMORANO, A.; MORILLO, A.; MORILLO, Y.; MÚÑOZ, J. Caracterización Molecular con Microsatélites Aleatorios RAMs, de la Colección de mora Rubus spp. In: SEMINAR OF BIOTECHNOLOGY, 9, 2004. Anais.... Palmira: Universidad Nacional de Colombia, 2004. 